\title{
ENERGY EXPENDITURE RANGES AND MUSCULAR WORK GRADES
}

\author{
BY
}

\author{
J. R. BROWN* and G. P. CROWDEN
}

From the Department of Applied Physiology, London School of Hygiene and Tropical Medicine

(RECEIVED FOR PUBLICATION JANUARY 31, 1963)

This paper is based on the findings of a field study which was planned to ascertain by metabolic measurement the rates of energy expenditure of men and women on productive effort at work in modern factories.

The investigation which is described was carried out during a period of peace-time full employment, mainly in factories associated with the Slough Industrial Health Service in which a nutritional survey of the calorie intake of male operatives had been made by the Ministry of Health and the Medical Research Council in 1952.

The rates of energy expenditure of 70 men and 54 women in 27 occupational groups were measured by indirect calorimetric methods. On the basis of the criteria for the classification of work according to its heaviness, adopted by the Factory Department of the Ministry of Labour, muscular work grades have been ascribed to the occupations studied.

From the distribution of 390 metabolic measurements, ranges of energy expenditure have been computed for occupations classed as sedentary, light, moderate, heavy, or very heavy, Observation of recurrent phase variations in types of productive effort in the work-cycle indicated that wider work grades, such as light-to-moderate or moderate-to-heavy, are needed to cover the energy expenditure rates of men and women in many occupations.

The data obtained in this study have enabled a table termed the "Slough Scales" to be compiled giving ranges of energy expenditure and pulmonary ventilation rates for the various work grades ascribed to occupations.

The mean rates of energy expenditure of 257 workers (in industries in different parts of England and Scotland) which have been calculated from data published by other investigators have been found to fall within the ranges specified in these scales for the work grades of their occupations. It is felt, therefore, that the Slough Scales represent a reasonably true appraisal of the relation between the Ministry of Labour occupational work grades and the rates of energy expenditure of men and women at work under environmental and management conditions which usually appertain in the United Kingdom.

Many scales or tables giving the calorie requirements of men and women engaged in occupations involving muscular work of varying degrees of severity have been drawn up (Voit, 1881; Atwater, 1893; Lusk, 1918; Royal Society, 1919; and Hawley, 1927). In the past such scales have usually been based on the daily food intake, expressed as calories, of different sections of the population. The foodcalorie value and qualitative composition of the diet required per day by an average adult male to main-

*Present address: Department of Physiological Hygiene, School of Hygiene, University of Toronto. tain body weight whilst engaged on moderately heavy work has been used as a basis from which the requirements of workers in light or heavy occupations have been estimated.

The calorie requirements of individuals may also be computed from records of the time spent on various daily activities including sleep coupled with the rates of energy expenditure as measured by indirect calorimetry for each type of activity (Orr and Leitch, 1938). The classification of muscular work according to its intensity was investigated and discussed from the physiological point of view by Dill (1936). 
The International Labour Office of the League of Nations (1936) and the British Medical Association (Committee on Nutrition, 1950) published scales of energy expenditure in terms of net (additional) calories per hour required for occupational activities to supplement individual basal requirements. It was noted that the appropriate classification of occupations as light or heavy was "a matter of no little uncertainty" in view of the limited amount of data regarding energy expenditure by workers in industries as they operate today.

In recent times advances in methods of indirect calorimetry have led to an increased knowledge of the metabolic cost per minute of muscular work carried out in occupational and other activities and made it possible to calculate the daily energy requirements of individuals with greater precision.

Bransby (1954) reported a dietary survey carried out by the Ministry of Health and the Medical Research Council on men working in factories associated with the Slough Industrial Health Service. The total calorie intake per man was estimated from measurements of the food consumed, and, using energy expenditure rates for ordinary routine daily activities published by other workers, the average calorie expenditure per minute in excess of basal requirements was calculated for light to heavy work grades. Extensive dietary surveys have been carried out by Widdowson, Edholm, and McCance (1954) on military cadets and coupled with energy expenditure measurements by Edholm, Fletcher, Widdowson, and McCance (1955) on similar groups, and by Garry, Passmore, Warnock and Durnin (1955) on miners and clerks in the East Fife coalfield. Tables giving the metabolic cost (kcal./min.) of activity observed in these field studies and calculated from the energy expenditure data published by investigators in the United States of America and in several European countries have been compiled by Passmore and Durnin (1955).

Apart from occupational supplements, the calorie requirements of adult men and women for maintenance have also been considered in relation to age, body weight, and environmental temperature (Food and Agricultural Organization, 1950; 1957).

In a preliminary communication on the grading of muscular work (Brown and Crowden, 1956), attention was drawn to variations in published scales of energy expenditure rates for light, moderate, and heavy work. It was noted that the classification of occupations might vary considerably according to whether the scale of reference used was that of the British Medical Association (1950) or Christensen (1953).

In the present study the "Slough Scale" of ranges of energy expenditure for sedentary to very heavy work given in Table 4 has been compiled from actual measurements of the metabolic rates of 70 men and 54 women whilst they were performing various types of muscular work in productive effort in 27 occupational groups during a post-war period of stable full employment in modern industry. In drawing up this scale, after the metabolic measurements had been made, the occupations were graded according to the criteria for work classification adopted by H.M. Factory Inspectorate of the Ministry of Labour and National Service (Bransby, 1954), and the ranges of energy expenditure as measured during the performance of productive effort by the men and women factory workers were associated with each grade of work.

\section{Method}

Selection of Subjects.-During the dietary survey in factories at Slough (Bransby, 1954) the types of work carried out in various occupations were noted with a view to the present metabolic study in which the rates of energy expenditure of men and women at work would be measured. With the concurrence of the management and representatives of the employees to whom the objects of the investigation were explained and methods of measuring energy expenditure at work were demonstrated, men and women in occupations involving sedentary, light, moderate or heavy work were asked to volunteer as subjects. There was no shortage of volunteers and as many as possible were subsequently used for the metabolic determinations at work.

It should be noted, however, that before selecting, or rather finally accepting an individual volunteer as a subject he or she was required to pass a medical examination which was carried out in the medical department of the factory with the co-operation of the works' medical officer. In this examination special attention was paid to detecting any physical defects which might limit the individual's working capacity, in particular cardiorespiratory abnormalities and deformities of the skeletal system. If defects were detected at this examination the individual was not accepted as a subject and a few volunteers who passed were not subsequently used for the actual metabolic measurements during work if they showed difficulty in adapting themselves to wearing the face-mask (vide Figs. 1 and 2) and breathing through the respirometer during the routine pre-test trial run referred to below.

The measurement of oxygen requirement interested the subjects as articles had appeared in the press commenting on the possible advantage to footballers of breathing oxygen before play. It is believed that this encouraged the factory workers to volunteer as subjects, likewise the publication in their works magazine of an illustrated article on "Oxygen requirement for work". These points are recorded because it is essential to gain the co-operative understanding of the individuals who are required to participate as subjects in field investigations of this nature.

Anthropometric measurements, nude-weight, and height without shoes were taken at the time of the 


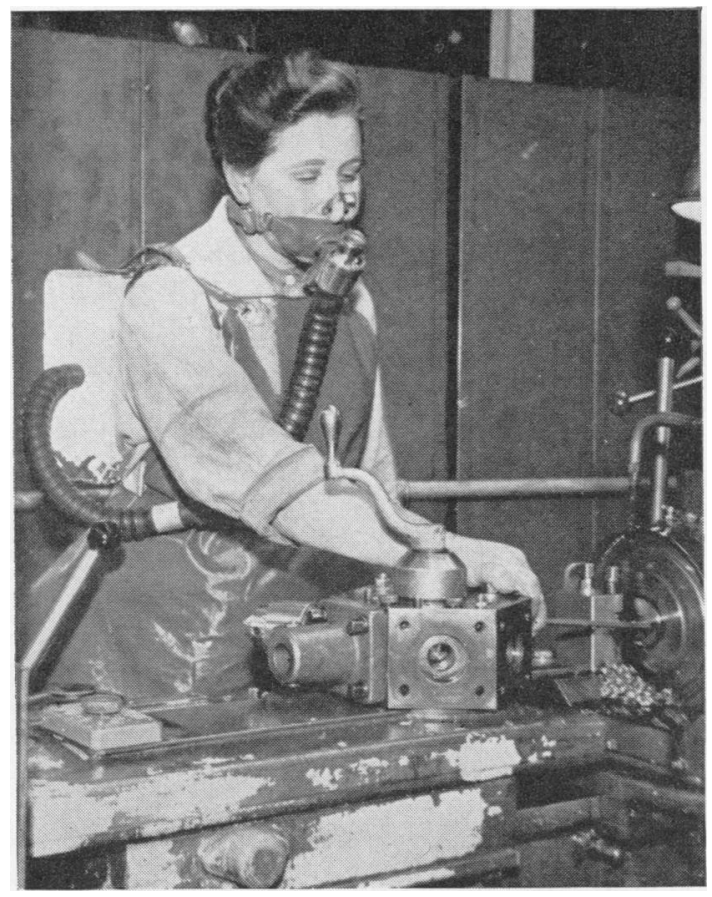

FIG. 1.-Capstan lathe operative with portable respirometer fitted and adjusted so that it does not impede normal work performance.

medical examination and recorded on the job-analysis cards of the individuals selected as suitable subjects for the subsequent metabolic determinations at work.

Pre-test Routine.-As a routine all subjects were first observed during the course of their normal working day, with particular reference to the regularity, type, variations in, and duration of their productive work spells. The pre-test observations of the work-cycle and posture of the subjects were recorded in order to enable the investigators to detect any departure from their normal work routine during actual metabolic measurements.

Before the commencement of every determination the portable metabolism apparatus was carefully fitted and adjusted to the subject so that it would not interfere with his or her productive effort (Fig. 1). Each subject was given a trial run breathing through the respirometer and it was emphasized that during the subsequent 10-minute tests it was most important to adhere to the normal rate and rhythm of working so that the oxygen actually required per minute could be measured.

Metabolic Measurements and Timing.--Indirect calorimetric determinations of the rates of energy expenditure of the subjects at work were made during predetermined representative portions of their productive effort. The portable respirometer designed by Müller and Franz (1952) after Kofrányi and Michaelis (1940) was used for measuring ventilation volumes and collecting samples of expired air over periods of 10 to 15 minutes on three or more occasions for each subject.

The tests were usually made during the middle of the morning or middle of the afternoon shifts. As the jobs studied generally involved repetitive work over long periods, it was considered that the subjects would be in a steady state (Hill, Long, and Lupton, 1924) and that metabolic determinations made at these times would give a reasonably accurate measure of their rates of energy expenditure at work. Photographic records, including 16 $\mathrm{mm}$. cine films of their productive effort and posture, were taken during the tests.

The samples of expired air were analysed within a very short time after the completion of each test, this being greatly facilitated by the provision of a mobile laboratory, equipped with Haldane gas analysis apparatus, which was located in close proximity to the factories, sometimes for many weeks while the investigation was in progress.

Environmental Conditions.-As excessive heat or cold might affect work performance, the environmental conditions were assessed as a routine at the time of the metabolic measurements. The following observations were taken: air temperature, dry bulb and wet bulb; air velocity; mean radiant temperature; and corrected effective temperature (Bedford, 1946), using the globe thermometer, silvered thermometer, and high temperature silvered katathermometer for the purpose.

From time to time samples of the ambient air were taken and analysed for $\mathrm{O}_{2}$ and $\mathrm{CO}_{2}$ so that variations in the percentage composition of inspired air could be allowed for when calculating the oxygen used by the subjects during the tests.

Tabulation of Data.- The anthropometric, occupational and metabolic data for each subject were tabulated in the following sequence in order to facilitate statistical compu-

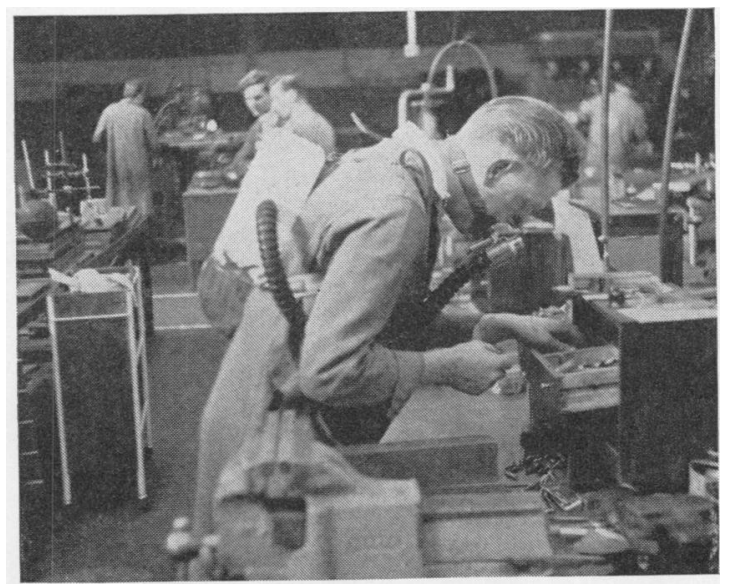

FIG. 2.-Tool-room operative fitted with respirometer for measuring and sampling his expired air during work. A globe thermometer and other instruments used for assessing environmental warmth are shown on the trolley behind the subject. 
tation and the determination of the ranges of energy expenditure for the work grades of the occupations studied (Brown, 1959):

$\begin{array}{lll}\begin{array}{lll}\text { Subject's reference } \\ \text { Name }\end{array} & \begin{array}{l}\text { Ventilation } \\ \text { Ventilation } \\ \text { Gex }\end{array} & \begin{array}{l}1 . / \mathrm{min} . \\ \text { equivalent } \\ \mathrm{O}_{2} \mathrm{cc} . / \mathrm{min} .\end{array} \\ \text { Age } & \text { Gross } & \mathrm{kcal} / \mathrm{min} . \\ \text { Height }(\mathrm{cm} .) & \text { Gross } & \mathrm{kcal} . / \mathrm{hr} . \\ \text { Weight }(\mathrm{kg} .) & \text { Gross } & \mathrm{kcal} / \mathrm{m}^{2} . / \mathrm{hr} . \\ \left.\text { Surface area (m. }{ }^{2}\right) & \text { Gross } & \mathrm{kcal} . / \mathrm{kg} . / \mathrm{hr} \\ \text { Job } & \text { Basal } & \mathrm{O}_{2} \mathrm{cc} . / \mathrm{min} . \\ \text { Date and time } & \text { Net } & \mathrm{O}_{2} \mathrm{cc} . / \mathrm{min} . \\ \text { Observation no. } & \text { Net } & \mathrm{kcal} . / \mathrm{min} . \\ & \text { Net } & \mathrm{kcal} . / \mathrm{hr} . \\ & \text { Net } & \mathrm{kcal} . / \mathrm{m}^{2} . / \mathrm{hr} .\end{array}$

Results

Occupational Groups Studied.-The rates of energy expenditure of 70 men and 54 women factory workers were determined by indirect calorimetry while they were engaged on productive effort, 390 measurements of the metabolic cost of working at their normal rates being made. The subjects were drawn from 27 occupational groups as indicated in Table 1,

TABLE 1

\begin{tabular}{|c|c|c|}
\hline Work grade & Occupational Group & $\begin{array}{l}\text { No. of } \\
\text { Obser- } \\
\text { vations }\end{array}$ \\
\hline Sedentary & $\begin{array}{l}\text { Mechanical accounting } \\
\text { Hollerith machine operator }\end{array}$ & $\begin{array}{l}23 \\
12\end{array}$ \\
\hline Sedentary-to-light & Gasket inspection & 13 \\
\hline Light & $\begin{array}{l}\text { Machine minding } \\
\text { Frame cutting } \\
\text { Gasket packing } \\
\text { Canteen work }\end{array}$ & $\begin{array}{r}17 \\
6 \\
14 \\
11\end{array}$ \\
\hline Light-to-moderate & $\begin{array}{l}\text { Tapping and drilling } \\
\text { Tool making } \\
\text { Capstan lathe work } \\
\text { Gasket roller press work } \\
\text { Router machine work } \\
\text { Medium press work } \\
\text { Eyelet press work } \\
\text { Small press work } \\
\text { Printing press work }\end{array}$ & $\begin{array}{r}6 \\
14 \\
3 \\
3 \\
2 \\
28 \\
18 \\
48 \\
15\end{array}$ \\
\hline Moderate & $\begin{array}{l}\text { Hand press work } \\
\text { Annealing } \\
\text { Gasket supply }\end{array}$ & $\begin{array}{r}18 \\
8 \\
13\end{array}$ \\
\hline Moderate-to-heavy & $\begin{array}{l}\text { General labouring } \\
\text { Power truck driving } \\
\text { Copper and card cutting } \\
\text { Washing and filling carboys }\end{array}$ & $\begin{array}{r}10 \\
17 \\
8 \\
22\end{array}$ \\
\hline Heavy & $\begin{array}{l}\text { Filling and stacking } 1 \mathrm{cwt} \text {. bags } \\
\text { Loading and unloading } 1 \text { cwt. } \\
\text { bags } \\
\text { Hopper loading }\end{array}$ & $\begin{array}{l}16 \\
24 \\
14\end{array}$ \\
\hline Heavy-to-very heavy & Furnace cleaning & 7 \\
\hline
\end{tabular}

which also shows the number of observations made on each group and the work grade ascribed to their occupations by the Ministry of Labour.
Anthropometric Measurements.-The anthropometric data for 70 men and 54 women factory workers who participated as subjects in the metabolic determinations are given in summary form in Táble 2.

TABLE 2

ANTHROPOMETRIC DATA OF SUBJECTS

\begin{tabular}{|c|c|c|c|c|}
\hline & Range & Mean & S.D. & Coefficient $V$ \\
\hline $\begin{array}{l}70 \text { Males } \\
\text { Age (yr.) } \\
\text { Height (cm.) } \\
\text { Weight (kg.) }\end{array}$ & $\begin{array}{c}16-56 \\
149-193 \\
44 \cdot 0-93 \cdot 0\end{array}$ & $\begin{array}{r}32.5 \pm 1 \cdot 21 \\
170.2 \pm 0.92 \\
66.4 \pm 10.2\end{array}$ & $\begin{array}{r}10 \cdot 1 \\
7 \cdot 7 \\
10 \cdot 2\end{array}$ & $\begin{array}{r}31 \cdot 0 \\
4 \cdot 5 \\
15 \cdot 4\end{array}$ \\
\hline $\begin{array}{l}54 \text { Females } \\
\text { Age (yr.) } \\
\text { Height (cm.) } \\
\text { Weight (kg.) }\end{array}$ & $\begin{array}{c}16-60 \\
147-173 \\
40 \cdot 8-104 \cdot 8\end{array}$ & $\begin{array}{r}30.0 \pm 1 \cdot 37 \\
158.4 \pm 0.87 \\
58.6 \pm 1.39\end{array}$ & $\begin{array}{r}10 \cdot 1 \\
6 \cdot 4 \\
10 \cdot 2\end{array}$ & $\begin{array}{r}33 \cdot 7 \\
4 \cdot 1 \\
17 \cdot 3\end{array}$ \\
\hline
\end{tabular}

Energy Expenditure and Work Grades.-The metabolic data obtained by indirect calorimetric measurements on 70 men and 54 women factory workers were recorded on 390 occasions during the performance of the various types of productive effort called for by their occupations which ranged from sedentary to very heavy.

The grading ascribed to each occupation was based on the information recorded on the job analysis cards of the individual workers and the Ministry of Labour criteria for the classification of industrial work according to its heaviness, namely, the weight of objects lifted and handled, the method of lifting, the use of mechanical aids, the speed of working, rest pauses, and the length of the working shift.

In order to determine the ranges in rates of energy expenditure for each grade of work the distribution of the 390 metabolic measurements expressed in terms of $\mathrm{kcal} . / \mathrm{m}^{2} . / \mathrm{hr}$. was tabulated (Table 3 ).

A detailed examination of this table showed that in terms of $\mathrm{kcal} . / \mathrm{m}^{2} . / \mathrm{hr}$. the following ranges of energy expenditure appeared to be the most appropriate for each of the work grades: sedentary, 40 to 70 ; light, 70 to 110 ; moderate, 110 to 180 ; heavy, 180 to 300 ; and very heavy, $300+$.

While these ranges for work grades apply to occupations characterized by continuous work involving uniform types of productive effort and posture, wider ranges of energy expenditure are needed to cover occupations in which the physical demands on the operative vary considerably in the course of the work shift. Pre-test observations of the men and women subjects at work and subsequent metabolic measurements showed that, whereas some occupations involved light and moderate phases of effort, others ranged from moderate to heavy, or heavy to very heavy. The Ministry of Labour grading of such occupations takes into account variations in physical demands in the work cycle, and 
TABLE 3

DISTRIBUTION OF ENERGY EXPENDITURE RATES OBSERVED DURING WORK RANGING FROM SEDENTARY TO VERY HEAVY

\begin{tabular}{|c|c|c|c|c|c|c|c|c|c|c|c|c|c|c|c|c|c|c|}
\hline \multirow{2}{*}{$\begin{array}{l}\text { Ministry of Labour } \\
\text { Work Grade }\end{array}$} & \multirow{2}{*}{$\begin{array}{c}\text { No. of } \\
\text { Observations }\end{array}$} & \multicolumn{17}{|c|}{ Kilogramme-calories per Square Metre per Hour } \\
\hline & & 40 & 50 & 60 & 70 & 80 & 90 & 100 & 110 & 120 & 130 & 140 & 150 & 160 & 170 & 180 & 190 & 200 \\
\hline $\begin{array}{l}\text { Sedentary } \\
\text { Sedentary-to-light } \\
\text { Light } \\
\text { Light-to-moderate } \\
\text { Moderate } \\
\text { Moderate-to-heavy } \\
\text { Heavy } \\
\text { Heavy-to-very heavy } \\
\text { Total }\end{array}$ & $\begin{array}{r}35 \\
13 \\
48 \\
137 \\
39 \\
57 \\
54 \\
7 \\
390\end{array}$ & & $\begin{array}{l}2 \\
1\end{array}$ & $\begin{array}{r}11 \\
1 \\
1 \\
2\end{array}$ & $\begin{array}{r}17 \\
3 \\
1 \\
12 \\
2\end{array}$ & $\begin{array}{r}4 \\
7 \\
7 \\
27 \\
1\end{array}$ & $\begin{array}{r}1 \\
2 \\
9 \\
23 \\
3 \\
3 \\
\\
\\
41\end{array}$ & $\begin{array}{r}17 \\
22 \\
5 \\
1 \\
45\end{array}$ & $\begin{array}{r}7 \\
14 \\
1 \\
3 \\
\\
25\end{array}$ & $\begin{array}{r}4 \\
17 \\
5 \\
5\end{array}$ & $\begin{array}{r}2 \\
8 \\
2 \\
4 \\
\\
\\
16\end{array}$ & $\begin{array}{r}5 \\
1 \\
5 \\
3 \\
14\end{array}$ & $\begin{array}{r}3 \\
6 \\
6 \\
1 \\
16\end{array}$ & $\begin{array}{r}1 \\
4 \\
6 \\
4 \\
15\end{array}$ & $\begin{array}{r}1 \\
6 \\
3 \\
2 \\
1 \\
13\end{array}$ & $\begin{array}{r}1 \\
1 \\
9 \\
4 \\
15\end{array}$ & $\begin{array}{r}2 \\
3 \\
5 \\
10\end{array}$ & $\begin{array}{l}2 \\
1 \\
3\end{array}$ \\
\hline \multirow{2}{*}{$\begin{array}{l}\text { Ministry of Labour } \\
\text { Work Grade }\end{array}$} & \multirow{2}{*}{$\begin{array}{l}\text { No. of } \\
\text { Observations }\end{array}$} & \multicolumn{17}{|c|}{ Kilogramme-calories per Square Metre per Hour } \\
\hline & & 210 & 220 & & 230 & 240 & 250 & 260 & 270 & 280 & 290 & 300 & 310 & 320 & 330 & 340 & 350 & 360 \\
\hline $\begin{array}{l}\text { Sedentary } \\
\text { Sedentary-to-light } \\
\text { Light } \\
\text { Light-to-moderate } \\
\text { Moderate } \\
\text { Moderate-to-heavy } \\
\text { Heavy } \\
\text { Heavy-to-very heavy } \\
\text { Total }\end{array}$ & $\begin{array}{r}35 \\
13 \\
48 \\
137 \\
39 \\
57 \\
54 \\
7 \\
79\end{array}$ & $\begin{array}{r}1 \\
9 \\
10\end{array}$ & $\begin{array}{l}3 \\
5\end{array}$ & & $\begin{array}{l}1 \\
7 \\
1 \\
9\end{array}$ & $\begin{array}{l}2 \\
2 \\
4\end{array}$ & $\begin{array}{l}4 \\
4\end{array}$ & 3 & $\begin{array}{l}2 \\
1 \\
3\end{array}$ & & $\begin{array}{l}\mathbf{2} \\
\mathbf{1} \\
\mathbf{3}\end{array}$ & $\begin{array}{l}2 \\
2\end{array}$ & & & & & & 1 \\
\hline
\end{tabular}

TABLE 4

ENERGY EXPENDITURE AND PULMONARY VENTILATION RANGES IN RELATION TO WORK GRADES: THE "SLOUGH SCALES"

\begin{tabular}{|c|c|c|c|c|}
\hline \multirow{2}{*}{ Work Grade } & \multicolumn{3}{|c|}{ Energy Expenditure } & \multirow{2}{*}{$\begin{array}{l}\text { Pulmonary } \\
\text { Ventilation } \\
\text { (l./kg./min.) }\end{array}$} \\
\hline & Gross (kcal./m²./hr.) & Gross (kcal./min.) & Net (kcal./hr.) & \\
\hline $\begin{array}{l}\text { Sedentary } \\
\text { Sedentary-to-light } \\
\text { Light } \\
\text { Light-to-moderate } \\
\text { Moderate } \\
\text { Moderate-to-heavy } \\
\text { Heavy } \\
\text { Heavy-to-very heavy }\end{array}$ & $\begin{array}{l}40-70 \\
40-110 \\
70-110 \\
70-180 \\
110-180 \\
110-300 \\
180-300 \\
180-300+\end{array}$ & $\begin{array}{l}1 \cdot 1-2 \cdot 0 \\
1 \cdot 1-3 \cdot 0 \\
2 \cdot 0-3 \cdot 0 \\
2 \cdot 0-5 \cdot 0 \\
3 \cdot 0-5 \cdot 0 \\
3 \cdot 0-8 \cdot 0 \\
5 \cdot 0-8 \cdot 0 \\
5 \cdot 0-8 \cdot 0\end{array}$ & $\begin{array}{c}6-60 \\
6-120 \\
60-120 \\
60-240 \\
120-240 \\
120-420 \\
240-420 \\
240-420+\end{array}$ & $\begin{array}{c}<0 \cdot 12 \\
<0 \cdot 12-0 \cdot 20 \\
0 \cdot 12-0 \cdot 20 \\
0 \cdot 12-0 \cdot 30 \\
0 \cdot 20-0 \cdot 30 \\
0 \cdot 20-0 \cdot 50 \\
0 \cdot 30-0 \cdot 50 \\
0 \cdot 30-0 \cdot 50+\end{array}$ \\
\hline
\end{tabular}

Table 4 gives the Slough Scales, so called because they were mainly based on metabolic measurements on workers in factories associated with the Slough Industrial Health Service. They include kcal. $/ \mathrm{m}^{2} . / \mathrm{hr}$. (gross) ranges in energy expenditure, also equivalent ranges in terms of kcal./min. (gross), kcal./hr. (net) and $1 . / \mathrm{kg} . / \mathrm{min}$., the pulmonary ventilation per minute in relation to the body weight of the individual.

\section{Discussion}

A question which naturally arises when considering the Slough Scales (Table 4) is whether the ranges of energy expenditure given for the various work grades do, in fact, apply to occupations carried out in other parts of this country.

In an attempt to answer this question the anthropometric data and energy expenditure rates of 257 industrial workers, 172 men and 85 women, in 27 occupations including coal-mining in Scotland,
TABLE 5

RATES OF ENERGY EXPENDITURE OF 257 INDUSTRIAL WORKERS FALLING WITHIN THE KCAL./M./HR. SLOUGH SCALE RANGES FOR THE WORK GRADES OF THEIR OCCUPATIONS

\begin{tabular}{l|c|c|cc}
\hline \multirow{2}{*}{ Work Grade } & $\begin{array}{c}\text { No. of } \\
\text { Subjects }\end{array}$ & $\begin{array}{c}\text { Slough Scale } \\
\text { Range } \\
\text { (kcal./m²./hr. })\end{array}$ & \multicolumn{2}{|c}{$\begin{array}{c}\text { Observations } \\
\text { within Range }\end{array}$} \\
\cline { 4 - 5 } & Sedentary & No. & $\%$ \\
\hline Sedentary-to-light & 10 & $40-70$ & 45 & 90 \\
Light & 37 & $70-110$ & 10 & 100 \\
Light-to-moderate & 87 & $70-180$ & 85 & 69 \\
Moderate-to-heavy & 17 & $110-300$ & 17 & 100 \\
Heavy-to-very & 56 & $180-300+$ & 50 & 89 \\
\hline heavy & 257 & & 231 & 89.9 \\
\hline Total & & &
\end{tabular}

published by Greenwood, Hodson and Tebb (1919), Rosenheim (1919), Turner (1955), and Garry et al. (1955), have been studied and compared with the Slough Scale ranges for their occupational work grades. 
In respect of their anthropometric characteristics the groups of workers were found to be similar with the exception of Greenwood's 44 women munition workers whose mean height was calculated to be 3.5 $\mathrm{cm}$. greater than that shown for the 54 women subjects in Table 2 above. It is possible that this difference may be accounted for by the method of measurement adopted by Greenwood as he gave no indication whether the heights were measured with or without shoes.

From the metabolic data and information given in these earlier reports, the mean $\mathrm{kcal} . / \mathrm{m}^{2} . / \mathrm{hr}$. rates of energy expenditure of 257 subjects have been calculated and their occupations graded as far as possible according to the criteria for work classification adopted by the Ministry of Labour. In order to check the validity of the Slough Scales when applied to these occupations, the number and percentage of these 257 independent observations of energy expenditure falling within the Slough Scale ranges specified for their occupational work grades have been calculated and listed in Table 5. The fact, as shown in this table, that the over-all correspondence was found to be $89.9 \%$ strongly supports the validity

TABLE 6

RANGES AND MEAN RATES OF ENERGY EXPENDITURE OF 381 SUBJECTS, 242 MEN AND 139 WOMEN, IN 54 OCCUPATIONS, AND "SLOUGH SCALE" RANGES

\begin{tabular}{|c|c|c|c|c|c|c|}
\hline \multirow{2}{*}{ Work Grade } & \multirow{2}{*}{ Occupation } & \multicolumn{2}{|c|}{ Subjects } & \multicolumn{3}{|c|}{ Energy Expenditure (kcal.//2 $\mathbf{2} / \mathrm{hr}$ ) } \\
\hline & & $\mathbf{M}$ & $\mathbf{F}$ & Range & Mean & Slough Scale \\
\hline Sedentary & $\begin{array}{l}\text { Mechanical A/c } \\
\text { Hollerith } \\
\text { Typist } \\
\text { Tailor } \\
\text { Draughtsman } \\
\text { Inspector } \\
\text { Watch repairer } \\
\text { Clerk }\end{array}$ & $\begin{array}{l}\frac{2}{9} \\
\frac{5}{8} \\
9\end{array}$ & $\begin{array}{r}17 \\
2 \\
5 \\
- \\
4 \\
-\end{array}$ & $\begin{array}{l}37 \cdot 0-80 \cdot 7 \\
46 \cdot 1-74 \cdot 6 \\
57 \cdot 0-76 \cdot 0 \\
49 \cdot 0-67 \cdot 0 \\
51 \cdot 0-75 \cdot 0 \\
56 \cdot 0-62 \cdot 0 \\
46 \cdot 0-60 \cdot 0 \\
40 \cdot 2-65 \cdot 9\end{array}$ & $\begin{array}{l}59 \cdot 0 \\
62 \cdot 1 \\
68 \cdot 0 \\
55 \cdot 0 \\
61 \cdot 0 \\
59 \cdot 0 \\
53 \cdot 0 \\
54 \cdot 4\end{array}$ & $40-70$ \\
\hline Sedentary-to-light & $\begin{array}{l}\text { Tally clerk } \\
\text { Gasket inspector }\end{array}$ & 10 & $\overline{4}$ & $\begin{array}{l}43 \cdot 0-91 \cdot 3 \\
57 \cdot 7-89 \cdot 2\end{array}$ & $\begin{array}{l}64 \cdot 6 \\
73 \cdot 1\end{array}$ & $40-110$ \\
\hline Light & $\begin{array}{l}\text { Machine minding } \\
\text { Frame cutting } \\
\text { Gasket packing } \\
\text { Canteen work } \\
\text { Light turning } \\
\text { Finishing } \\
\text { Boot and shoe repair }\end{array}$ & $\begin{array}{l}6 \\
2 \\
- \\
8 \\
1 \\
5\end{array}$ & $\begin{array}{r}- \\
6 \\
5 \\
6 \\
17 \\
-\end{array}$ & $\begin{array}{l}56 \cdot 6-123 \cdot 3 \\
77 \cdot 8-104 \cdot 8 \\
71 \cdot 5-115 \cdot 9 \\
74 \cdot 1-126 \cdot 2 \\
50 \cdot 6-98 \cdot 0 \\
50 \cdot 0-114 \cdot 0 \\
76 \cdot 0-117 \cdot 0\end{array}$ & $\begin{array}{l}90 \cdot 2 \\
90 \cdot 5 \\
96 \cdot 6 \\
92 \cdot 7 \\
72 \cdot 8 \\
81 \cdot 0 \\
97 \cdot 0\end{array}$ & $70-110$ \\
\hline Light-to-moderate & $\begin{array}{l}\text { Tapping and drilling } \\
\text { Tool making } \\
\text { Capstan lathe } \\
\text { Gasket roller } \\
\text { Router machine } \\
\text { Medium press } \\
\text { Small press } \\
\text { Eyelet (foot) press } \\
\text { Printing press } \\
\text { Plastic moulding } \\
\text { Ebonite moulding } \\
\text { Plate punching (battery) } \\
\text { Plate cutting (battery) } \\
\text { Machinist } \\
\text { Roller mill } \\
\text { Sheet metal work } \\
\text { Metal turning (shell cases) } \\
\text { Turning and finishing (shell cases) } \\
\text { Tool setting } \\
\text { Forging }\end{array}$ & $\begin{array}{r}2 \\
5 \\
\overline{5} \\
10 \\
= \\
5 \\
12 \\
7 \\
5 \\
14 \\
3 \\
8 \\
= \\
=\end{array}$ & $\begin{array}{l}- \\
\frac{1}{1} \\
\overline{15} \\
\frac{9}{1} \\
= \\
= \\
= \\
\bar{Z} \\
8 \\
5 \\
4\end{array}$ & $\begin{array}{r}109 \cdot 1-173 \cdot 3 \\
47 \cdot 4-155 \cdot 0 \\
88 \cdot 5-115 \cdot 3 \\
102 \cdot 1-112 \cdot 9 \\
124 \cdot 0-129 \cdot 8 \\
70 \cdot 8-137 \cdot 2 \\
65 \cdot 8-116 \cdot 9 \\
55 \cdot 1-114 \cdot 1 \\
72 \cdot 3-140 \cdot 6 \\
84 \cdot 0-148 \cdot 0 \\
96 \cdot 0-146 \cdot 0 \\
92 \cdot 0-135 \cdot 0 \\
82 \cdot 0-168 \cdot 0 \\
74 \cdot 0-144 \cdot 0 \\
101 \cdot 0-146 \cdot 0 \\
50 \cdot 0-144 \cdot 0 \\
58 \cdot 8-165 \cdot 6 \\
42 \cdot 6-186 \cdot 6 \\
69 \cdot 0-201 \cdot 6 \\
81 \cdot 0-160 \cdot 8\end{array}$ & $\begin{array}{r}140.9 \\
106.7 \\
106.1 \\
107.9 \\
126.9 \\
104.5 \\
82.9 \\
81.2 \\
97.6 \\
111.0 \\
112.0 \\
110.6 \\
113.0 \\
104.0 \\
129.0 \\
102.0 \\
96.0 \\
112.0 \\
124.0 \\
114.0\end{array}$ & $70-180$ \\
\hline Moderate & $\begin{array}{l}\text { Hand press } \\
\text { Annealing } \\
\text { Gasket supply }\end{array}$ & $\begin{array}{r}6 \\
2 \\
-\end{array}$ & $\frac{-}{4}$ & $\begin{array}{r}73 \cdot 0-165 \cdot 4 \\
88 \cdot 7-147 \cdot 9 \\
147 \cdot 5-195 \cdot 9\end{array}$ & $\begin{array}{l}121 \cdot 3 \\
119 \cdot 0 \\
170 \cdot 2\end{array}$ & $110-180$ \\
\hline Moderate-to-heavy & $\begin{array}{l}\text { Labourers } \\
\text { Power truck driver } \\
\text { Copper and card cutter } \\
\text { Carboy washer } \\
\text { Walking and carrying (shell cases) } \\
\text { Cleaning and drying (shell cases) } \\
\text { Gauging shell cases }\end{array}$ & $\begin{array}{r}4 \\
5 \\
3 \\
4 \\
- \\
-\end{array}$ & $\begin{array}{l}5 \\
- \\
3 \\
5 \\
4\end{array}$ & \begin{tabular}{r|}
$68 \cdot 7-206 \cdot 4$ \\
$83 \cdot 9-218 \cdot 4$ \\
$62 \cdot 6-177 \cdot 7$ \\
$83 \cdot 4-237 \cdot 8$ \\
$112 \cdot 2-207 \cdot 6$ \\
$109 \cdot 8-298 \cdot 2$ \\
$78 \cdot 0-235 \cdot 2$
\end{tabular} & $\begin{array}{l}147 \cdot 4 \\
164 \cdot 3 \\
115 \cdot 5 \\
158 \cdot 8 \\
161 \cdot 3 \\
182 \cdot 3 \\
154 \cdot 0\end{array}$ & $110-300$ \\
\hline Heavy & $\begin{array}{l}\text { Filling and stacking } 1 \text {-cwt. bags } \\
\text { Hopper loader } \\
\text { Loading and unloading carboys and 1-cwt. bags }\end{array}$ & $\begin{array}{l}4 \\
3 \\
4\end{array}$ & 二 & $\begin{array}{l}150 \cdot 9-248 \cdot 6 \\
203 \cdot 2-282 \cdot 9 \\
131 \cdot 8-256 \cdot 5\end{array}$ & $\begin{array}{l}200 \cdot 4 \\
241 \cdot 9 \\
187 \cdot 6\end{array}$ & $180-300$ \\
\hline Heavy-to-very heavy & $\begin{array}{l}\text { Furnace cleaning } \\
\text { Hewing coal } \\
\text { Girdering and timbering } \\
\text { Loading coal }\end{array}$ & $\begin{array}{r}2 \\
18 \\
18 \\
20\end{array}$ & $\bar{z}$ & $\begin{array}{l}161 \cdot 5-351 \cdot 7 \\
181 \cdot 8-364 \cdot 2 \\
143 \cdot 0-267 \cdot 3 \\
168 \cdot 6-325 \cdot 8\end{array}$ & $\begin{array}{l}267 \cdot 5 \\
241 \cdot 8 \\
195 \cdot 2 \\
243 \cdot 1\end{array}$ & $180-300+$ \\
\hline
\end{tabular}


of the Slough Scales derived from data obtained in the present study.

As a further check on the validity of the Slough Scales, the rates of energy expenditure of the 257 workers referred to in Table 5 and the 390 observations on 124 subjects in the present study have been combined in Table 6, together with the Slough Scale ranges for the work grades of their 54 occupational groups.

Individual differences in capacity for work, motivation, and recorded variations in rates of energy expenditure during different but recurrent phases of productive effort in the course of the work shift account, at least in part, for the wide ranges in $\mathrm{kcal} . / \mathrm{m}^{2} . / \mathrm{hr}$. rates shown for several occupational groups in Table 6 . However, it is of particular interest to note that without exception the mean $\mathrm{kcal} . / \mathrm{m}^{2} . / \mathrm{hr}$. rates for the 54 occupations listed in this table fell within the Slough Scale range for their various work grades. This fact is strong evidence that the Slough Scale represents a reasonably true appraisal of the relation which exists between occupational work grades and the rates of energy expenditure of men and women at work under environmental and management conditions which usually appertain in the United Kingdom. It must, however, be pointed out that work grades based on rates of energy expenditure as shown in Table 4, the Slough Scales, do not necessarily apply to workers in occupations in which the physical environment imposes thermal stress, or toxic hazards make it necessary for protective clothing and respirators to be worn. In such cases productive effort is harder for individuals to maintain than might be inferred from their rates of energy expenditure at work.

Apart from the $\mathrm{kcal} . / \mathrm{m}^{2} . / \mathrm{hr}$. (gross) ranges for work grades, Table 4 includes corresponding scales in terms of kcal./min. (gross), kcal./hr. (net), and pulmonary ventilation per kilogram body weight (1./kg./min.). The first two scales, viz. kcal. $/ \mathrm{m}^{2} . / \mathrm{hr}$. and $\mathrm{kcal} . / \mathrm{min}$., may be of use in physiological studies of work performance which call for the assessment of rates of energy expenditure of individuals. The kcal./hr. (net) scale may be of value in assessing the calorie requirements of population groups, while the scale giving ranges of pulmonary ventilation per kilogram body weight per minute may assist medical officers to ensure that new applicants are placed in jobs which are within their capacity for physical effort.

This research has been aided by grants for apparatus from the Central Research Fund of the University of London, for expenses in the field study from the Medical Research Council, and for statistical assistance from the Sir Halley Stewart Trust. Our thanks are also due to Dr. Austin Eagger, Director of the Slough Industrial Health Service, to the management and factory workers at Slough and in the London area, and to the Diet and Energy Committee of the Medical Research Council for their interest and support throughout the investigation.

\section{REFERENCES}

Atwater, W. O. (1893). Economy of food. Report Storrs Agric. Exp.

Sta., (1892), 5, 163 .
Bedford, T. (1946). Environmental warmth and its measurement. M.R.C. War Memo. No. 17. H.M.S.O., London.

Bransby, E. R. (1954). Brit. J. Nutr., 8, 100.

British Medical Association (1950). Report of the Committee on Nutrition. B.M.A., London.

Brown, J. R. (1959). The metabolic cost of muscular work in industry with special reference to variations in the rate of energy expenditure. Ph.D. thesis, University of London.

, and Crowden, G. P. (1956). J. Physiol., 133, 18-19P.
Christensen, E. H. (1953). Physiological valuation of work in the Nykroppa iron works. In Ergonomics Research Society Symposium on Fatigue, ed. Floyd, W. F. and Welford, A. T. Symposium on Fatigue, ed.
Pp. 93-108. Lewis, London.

Dill, D. B. (1936). Physiol, Rev., 16, 263.

Edholm, O. G., Fletcher, J. G., Widdowson, E. M., and McCance, R. A. (1955). Brit. J. Nutr., 9, 286.

Food and Agricultural Organization of the United Nations: Committee on Calorie Requirements (1950). F.A.O. Nutr. Stud. No. 5.

Report of Second Committee on Calorie Requirements (1957). F.A.O. Nutr. Stud. No. 15.

Garry, R. C., Passmore, R., Warnock, G. M., and Durnin, J. V. G. A. (1955). Studies on expenditure of energy and the consumption of food by miners and clerks, Fife, Scotland, 1952. Med. Res. Coun. spec. Rep. Ser. No. 289.

Greenwood, M., Hodson, C., and Tebb, A. E. (1919). Proc. roy. Soc., $\mathrm{B}, \mathbf{9 1}, \mathbf{6 2}$.

Hawley, E. (1927). Dietary scales and standards for measuring a family's nutritive needs. Bull. U.S. Dept. Agric., No. 8.

Hill, A. V., Long, C. H. N., and Lupton, H. (1924). Proc. roy. Soc. B, $\ddot{96}, 438$.

International Labour Office (1936). Report on the practical importance and application of nutritional principles to conditions existing in industry, Geneva. International Labour Office Studies and Reports. Series B, No. 23.

Kofrányi, E., and Michaelis, H. F. (1940). Arbeitsphysiologie, 11, 148. Lusk, G. (1918). J. Amer. med. Ass., 70, 821.

Müller, E. A., and Franz, H. (1952). Arbeitsphysiologie, 14, 499.

Orr, J. B. and Leitch, I. (1938). Nutr. Abstr. Rev., 7, 509.

Passmore, R., and Durnin, J. V. G. A. (1955). Physiol. Rev., 35, 801.

Rosenheim, Ö. (1919). Proc. roy. Soc. B, 91, 44.

Royal Society (1919). Food (War) Committee. Report on the food requirements of man and their variations according to age, sex, size and occupation. Harrison, London.

Turner, D. (1955). Brit. J. industr. Med., 12, 237.

Voit, C. (1881). Physiologie des allgemeinen Stoffwechsel und der Ernährung. Handbuch der Physiologie, Hermann, 5. (Quoted by Atwater, W. O. (1892). American and European dietaries and dietary standards. Report Storrs Agric. Exp. Sta., 4, 106.)

Widdowson, E. M., Edholm, O. G., and McCance, R. A. (1954). 